\title{
The Amino Acid Contents in Mangrove Rhizophora mucronata Leaves in Asahan, North Sumatra, Indonesia
}

\author{
Sri S. Ningsih ${ }^{1}$, Dafit Ariyanto ${ }^{2 *}$, Dian Puspitasari ${ }^{2}$, Anuraga Jayanegara ${ }^{3}$, Hamim Hamim ${ }^{4}$, and Heru Gunawan ${ }^{1}$ \\ ${ }^{1}$ Department of Agrotechnology, Faculty of Agriculture, Asahan University, Kisaran, Sumatera Utara, 21216, Indonesia \\ ${ }^{2}$ Department of Aquaculture, Faculty of Agriculture, University of Asahan, Kisaran, Sumatera Utara, 21216, Indonesia \\ ${ }^{3}$ Department of Nutrition and Feed Technology, Faculty of Animal Science, Bogor, IPB University, West Java, 16680, Indonesia \\ ${ }^{4}$ Department of Plant Biology, Faculty of Mathematics and Natural Sciences, Bogor, IPB University, West Java, 16680, Indonesia
}

\begin{abstract}
Amino acids are important components of mangrove plant metabolisms. The aim of this study was to determine the relationship of mangrove $R$. mucronata leaf colors to the amino acid content. This study was conducted between March to August 2019. The leaves were taken $50 \mathrm{~g}$. The assessment of Amino acids was conducted using UPLC Waters Acquity Class H with PDA Detector. The principal component analysis (PCA) was used to determine the relationship analysis between $R$. mucronata leaf colors and amino acid concentrations. The largest content was L - glutamic acid with a green leaf content of $6139.57 \pm 694.17 \mathrm{mg} / \mathrm{kg}$ and yellow leaf content of $6105.013 \pm 113.2058 \mathrm{mg} / \mathrm{kg}$. The results of PCA 1 showed that the influential amino acids were L-threonine (0.94), L-tyrosine (0.96), L-alanine (0.92), L-vanin (0.93), and PCA 2 showed glutamic acid (0.91). These results indicated that the difference in mangrove leaf colors affects the amino acid contents in the leaves.
\end{abstract}

Keywords: color, Rhizophoraceae, maturity leaves, Asahan Regency.

\section{Introduction}

Mangroves are distributed in tropical and sub-tropical tidal zones, mostly on the East coast of Northern Sumatra, Indonesia. Rhizophora mucronata is very important locally as a source of wood and non-wood products for the community. $R$. mucronata is a mangrove species that grows towards the sea on the coast and should be expected to be in the first line to experience the effects of global climate change, mainly due to rising sea levels [1]. Mangroves are the main source of carbon, vitamins, minerals, proteins, essential fatty acids, and energy that can be utilized for organisms and humans. Mangrove ecosystems have contributed to primary productivity in the aquatic environment in the form of leaf litters [2][3] and the litter experiences decomposition [4]. Mangroves contain various chemical compounds that can be used as medicine [5]; spawning grounds and nurseries for many fish and mollusks [6 - 8].

Mangroves adapt morphologically and physiologically to extreme conditions such as high salinity, extreme tides, temperature, and anaerobic soils [9]. Plants specifically adapt the morphology, structure and physiological mechanisms to the environment. Plants develop a large number of physiological and biochemical strategies to deal with stress [10]. Mangroves have potential bioactive sources [11]. Mangrove $R$. mucronata has an active compound [12]. These secondary plant metabolites are formed in plants and have a role in its protective mechanisms [13].
Amino acids have a very diverse and important role in plants for enzymes and proteins and provide important components for plant metabolism and structure. Overall, the amino acid content can represent up to $9 \%$ of mangrove leaf biomass [14]. In addition, they function as nitrogen $[\mathrm{N}]$ donors for the synthesis of various important compounds for plant development including nucleotides, chlorophyll, hormones, and secondary metabolites [15]. Amino acids are important components of plant metabolism, not only as protein constituents but also as important precursors of secondary metabolites and as carriers of organic nitrogen between plant organs [16]. Amino acids also affect plant growth and productivity [15]; intracellular $\mathrm{pH}$ control, metabolic energy generation or redox strength, and resistance to environmental stress [17]. The aim of this study was to determine the relationship of mangrove $R$. mucronata leaf maturity level based on colors to the amino acid contents.

\section{Materials and Methods}

\subsection{Time and Location of Research}

This research was conducted in March-August 2019. Mangrove leaf samples were collected from sahan Regency, North Sumatra, Indonesia (Figure 1.). Analysis of research data was performed at the GIS Laboratory, IPB University, Bogor. 


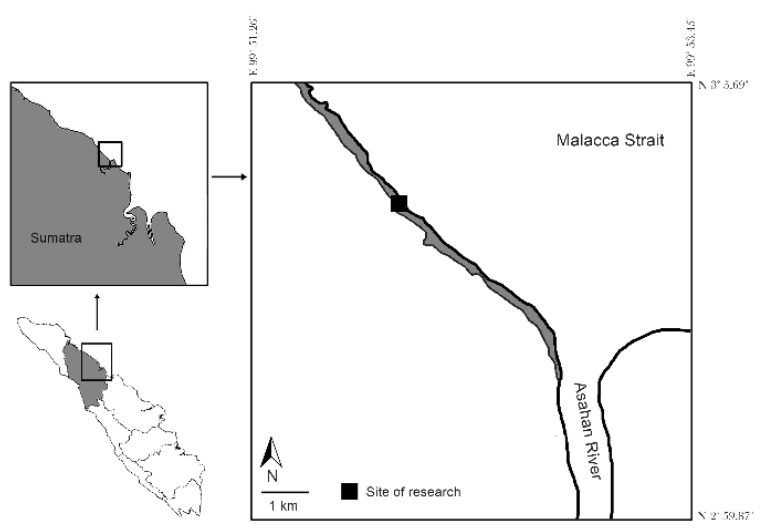

Figure 1. Site of research in Bagan Asahan Coast, North Sumatera, Indonesia.

\subsection{Amino acids analysis}

$2 \mathrm{~g}$ of $R$. mucronata leaf was extracted with $10 \mathrm{ml}$ of phosphate buffer $\mathrm{pH}$ 7.0. Total amino acid contents were determined after hydrolysis of pellet with $6 \mathrm{~N} \mathrm{HCl}$ at $100 \mathrm{IC}$ in vacuum hydrolysis tubes, for $24 \mathrm{hrs}$. After hydrolysis, the tubes were centrifuged at $3500 \mathrm{rpm}$ for 15 min and the supernatant was filtered. The filtrate was neutralized with $1 \mathrm{~N} \mathrm{NaOH}$ and diluted to $1: 100$ of the volume with milliQ-water. The analysis was performed by reverse-phase HPLC, HP-1101 Agilent Technologies with UV and Fluorescent detector 18.

\subsection{Statistical analysis}

Research data are expressed as mean \pm SEM. The principal component analysis (PCA) was used to determine the relationship analysis between leaf colors and amino acid concentrations. PCA displays data in a graphical form, data matrix, which consisted of leaf colors (lines) and variable of concentrations (columns). This analysis was performed using the 2018 Xlstat software.

\section{Results and Discussion}

Figure 2 shows that different leaf colors (green and yellow) had different amino acid contents. The largest content was L - glutamic acid with a green leaf content of $6139.57 \pm 694.17 \mathrm{mg} / \mathrm{kg}$ and yellow leaf content of $6105.013 \pm 113.2058 \mathrm{mg} / \mathrm{kg}$. The second-largest amino acid content was L-leucine with green leaf content of $5894.143 \pm 355.2384 \mathrm{mg} / \mathrm{kg}$ and yellow leaf content of $5301.183 \pm 174.1504 \mathrm{mg} / \mathrm{kg}$. Green leaf had the lowest histidine content compared to the others which were $3 \%$, while yellow leaf had the lowest L-tyrosine content of $2 \%$.

In general, amino acids have an important role in the various forms of chemical and biochemical processes in mangrove leaves. The presence and absence of different amino acids in a plant show specific reactions. Amino acids are generally present in various concentrations in $R$. mucronata mangrove leaves. Mangrove leaves experience a fall in the mangrove ecosystem. Amino acids are generally present in very low concentrations in sediments and it almost disappears below $10 \mathrm{~cm} \mathrm{[18].} \mathrm{The}$ abundant amino acid obtained in mangrove leaves in India is L-tyrosine [19].

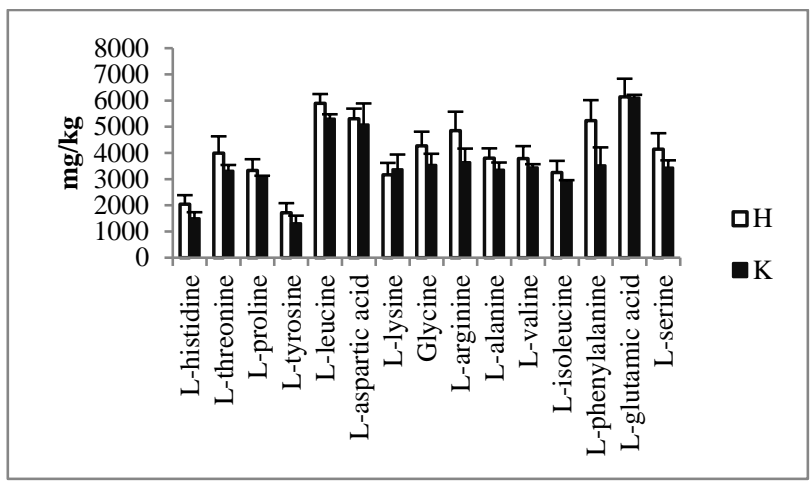

Figure 2. The difference in amino acid contents in the green and yellow leaves of mangrove $R$. mucronata.

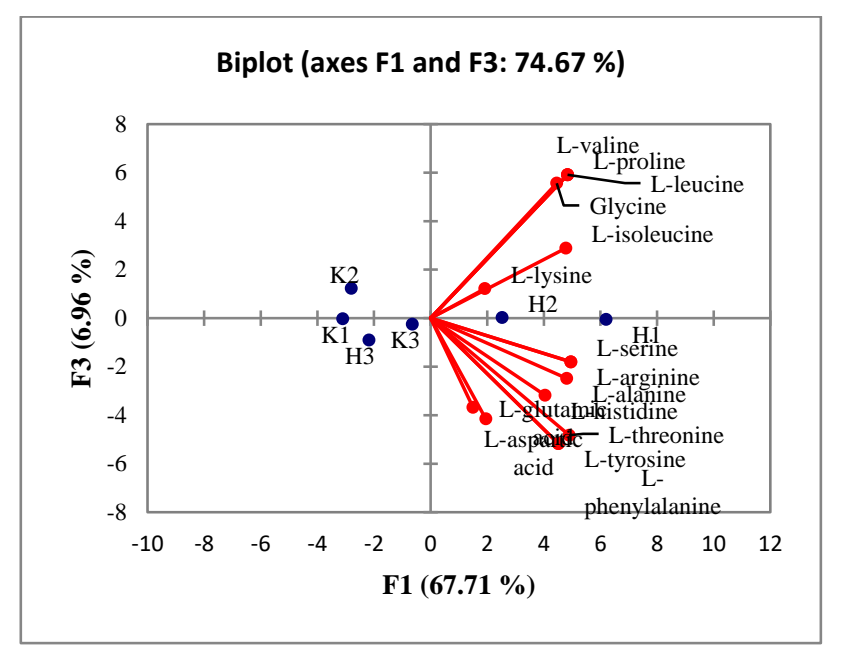

Figure 3. PCA analysis to determine the relationship of amino acid contents and leaf color differences in $R$. mucronata leaves.

The PCA analysis of the relationship between amino acid contents and leaf color differences in $R$. mucronata leaves showed 3 eigenvalues (Figure 3 ). The analysis of the first principal component had an eigenvalue of 10.156 (variance of $67.71 \%$ ), the second was 3.42 (variance of $22.75 \%$ ), and the third was 1.05 (variance of $6.96 \%$ ). Three eigenvalues indicated $97.42 \%$ data diversity (cumulative \% / total variance). The loading factor showed the relationship of the different colors effect of R. mucronata leaves generated PCA 1 including L-threonine (0.94), L-tyrosine (0.96), L-alanine (0.92), L-vanin (L93), and PCA 2 showed glutamic acid (0.91).

L-tyrosine is an essential aromatic amino acid needed for protein synthesis, a variety of natural plant products, plant growth and development [20]. L-tyrosine in plants also functions as a precursor in special metabolites that have diverse physiological roles as electron carriers, antioxidants, and defense compounds [21]. Some natural products of the tyrosine-derived plant are also used in medicine and nutrition. Glutamate occupies a central position in amino acid metabolism in plants formed by the action of glutamate synthase, using glutamine and 2-oxoglutarate [22]. The total concentration of amino acids in Rhizophora leaves with glutamic acid representing more than $10 \%$ [23]. 
The difference in the amino acid profile of the green leaf color was higher than the yellow leaf color. This indicated that the role of metabolism in plants has also decreased. Amino acids have a variety of prominent functions in plants. In addition to its function during protein biosynthesis, it also plays an important role during the process of plant stress responses [17].

\section{Conclusion}

The difference in the maturity level based on colors (green and yellow) of $R$. mucronata leaves affected the amino acid contents. Amino acids that were influential include L-threonin, L-tyrosine, L-alanine, L-vanin and produce the glutamic acid.

\section{Acknowledgment}

This research was supported by the 2019 Pekerti Grant, Ministry of Research, Technology and Higher Education, Republic of Indonesia.

\section{References}

1. Di Nitto D, Dahdouh-Guebas F, Kairo JG, et al.: Digital terrain modeling to investigate the effects of sea-level rise on mangrove propagule establishment. Mar Ecol Prog Ser. 2008; 356:175-88.

2. Ariyanto D, Bengen DG, Prartono T, et al.: Productivity and CNP availability in Rhizophora apiculata Blume and Avicennia marina (Forssk .) Vierh. at Banggi Coast, Central Java - Indonesia. AES Bioflux. 2018;10(3):137-46.

3. Ariyanto D, Bengen DG, Prartono $\mathrm{T}$, et al:: The Physicochemical Factors and Litter Dynamics (Rhizophora mucronata Lam . and Rhizophora stylosa Griff ) of Replanted Mangroves, Rembang, Central Java, Indonesia. Environ Nat Resour J. 2019;17(4):11-9.

4. Ariyanto D, Bengen DG, Prartono T, et al:: Short Communication : The relationship between content of particular metabolites of fallen mangrove leaves and the rate at which the leaves decompose over time. Biodiversitas. 2018;19(3):700-5.

5. Behbahani BA, Yazdi FT, Shahidi FN, et al:: Phytochemical analysis and antibacterial activities extracts of mangrove leaf against the growth of some pathogenic bacteria. Microb Pathog. 2018; 114:225-32. https://doi.org/10.1016/j.micpath.2017.12.004

6. Thomas N, Lucas R, Bunting $\mathrm{P}$, et al.: Distribution and drivers of global mangrove forest change, $1996-2010$. PLoS One. 2017;12(6):1-14.

7. Ariyanto $\mathrm{D}$, Bengen $\mathrm{DG}$, Prartono $\mathrm{T}$, et al:: The association of Cassidula nucleus (Gmelin 1791) and Cassidula angulifera (petit 1841) with mangrove in banggi coast, Central Java, Indonesia. AACL Bioflux. 2018;11(2):348-61.

8. Ariyanto D: Food preference on telescopium telescopium ( mollusca : gastropoda ) based on food sources in mangrove. Plant Arch. 2019;19(1):913-6.
9. Thatoi H, Behera BC, Mishra RR: Mycology: An International Journal on Fungal Biology Ecological role and biotechnological potential of mangrove fungi : a review. Mycol An Int J Fungal Biol. 2013;4(1):37-41.

10. Vinoth R, Kumaravel S, Ranganathan R: Anatomical and physiological adaptation of mangrove wetlands in east coast of Tamil Nadu. World Sci News. 2019;129:161-79.

11. Nebula M, Harisankar H, Candramohanakumar C: Metabolites and bioactivities of Rhizophoraceae mangroves. Nat Products Bioprospect. 2013;3(5):20732.

12. Aljaghthmi O, Heba H, Zeid IA : Bioactive Compounds Extracted from Mangrove Plants (Avicennia marina and Rhizophora mucronata): an Overview. Pathophysiology. 2018;1 -20 . https://doi.org/10.1016/j.pathophys.2018.09.002

13. Ignat I, Volf I, Popa VI: A critical review of methods for characterisation of polyphenolic compounds in fruits and vegetables. Food Chem. 2011;126(4):1821-35. http://dx.doi.org/10.1016/j.foodchem.2010.12.026

14. Hernes PJ, Benner R, Cowie GL, et al.: Tannin diagenesis in mangrove leaves from a tropical estuary: A novel molecular approach. Geochim Cosmochim Acta. 2001;65(18):3109-22.

15. Tegeder M, Rentsch D : Uptake and Partitioning of Amino Acids and Peptides. Mol Plant. 2010;3(6):9971011. http://dx.doi.org/10.1093/mp/ssq047

16. Dinkeloo K, Boyd S, Pilot G: Update on amino acid transporter functions and on possible amino acid sensing mechanisms in plants. Semin Cell Dev Biol. 2018;74:105-13. https://doi.org/10.1016/j.semcdb.2017.07.010

17. Hildebrandt TM, Nesi AN, Araújo WL, et al.: Amino acid catabolism in plants. Mol Plant 2015;8(11):1563-79. http://dx.doi.org/10.1016/j.molp.2015.09.005

18. Mulholland MR, Gobler CJ, Lee C: Peptide hydrolysis, amino acid oxidation, and nitrogen uptake in communities seasonally dominated by Aureococcus anophagefferens. Limnol Oceanogr. 2002;47(4):1094108.

19. Datta PN, Ghose M : Estimation of osmotic potential and free amino acids in some mangroves of the Sundarbans, India. Acta Bot Croat. 2003;62(1):37-45.

20. Shankar A, Agrawal N, Sharma M, et al.: Role of Protein Tyrosine Phosphatases in Plants. Curr Genomics. 2015;16(4):224-36.

21. Schenck CA, Maeda HA: Tyrosine biosynthesis, metabolism, and catabolism in plants. Phytochemistry. 2018;149:82-102.

https://doi.org/10.1016/j.phytochem.2018.02.003

22. Forde BG, Lea PJ : Glutamate in plants: Metabolism, regulation, and signalling. J Exp Bot. 2007;58(9):233958.

23. Zieman JC, Macko SA, Mills AL: Role of seagrasses and mangroves in estuarine food webs: temporal and spatial changes in stable isotope composition and amino acid content during decomposition. Bull Mar Sci. 1984;35(3):380-92. 